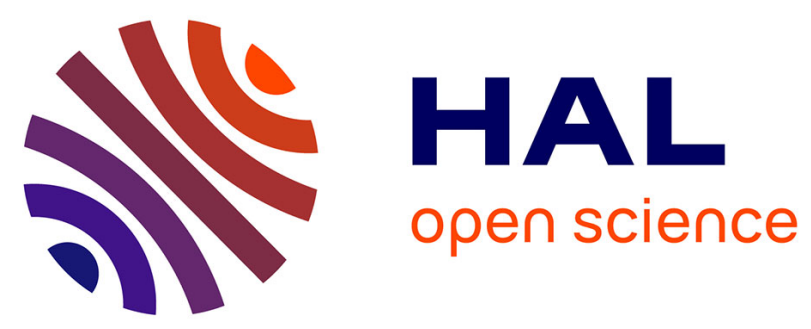

\title{
Genetic variation in production traits of Atlantic Salmon and Rainbow Trout \\ B. Gjerde
}

\section{To cite this version:}

B. Gjerde. Genetic variation in production traits of Atlantic Salmon and Rainbow Trout. Annales de génétique et de sélection animale, 1982, 14 (1), pp.113-113. hal-00893416

\section{HAL Id: hal-00893416 https://hal.science/hal-00893416}

Submitted on 1 Jan 1982

HAL is a multi-disciplinary open access archive for the deposit and dissemination of scientific research documents, whether they are published or not. The documents may come from teaching and research institutions in France or abroad, or from public or private research centers.
L'archive ouverte pluridisciplinaire HAL, est destinée au dépôt et à la diffusion de documents scientifiques de niveau recherche, publiés ou non, émanant des établissements d'enseignement et de recherche français ou étrangers, des laboratoires publics ou privés. 
as cryoprotectant. In average, embryos without morphological visible damages developed to 77.1 p. 100 (68.8 p. $100,85.7$ p. $100,83.3$ p. 100) during in vitro culture ; embryos with small partial damages only to 16.7 p. $100.5 / 12(41.7 \mathrm{p} .100)$ of the synchronised recipients were pregnant after non-surgical transfer of frozen thawed embryos. The work is still in progress for further development and improvement of the simple fast method for deepfreezing cow-embryos.

\title{
Genetic variation in production traits of Atlantic Salmon and Rainbow Trout
}

\section{B. GJERDE}

\author{
Department of Animal Genetics and Breeding \\ Agricultural University of Norway, $1432 \stackrel{\circ}{\mathrm{A} s-N L H, \text { Norway }}$
}

A study of genetic variation in production traits of Atlantic Salmon (Salmo salar) and Rainbow Trout (Salmo gairdneri) have been carried out. Heritabities for weight of fish were estimated at 0,37 in salmon and about 0.20 in Rainbow Trout. For maturity the heritabilities were found to be 0.42 in salmon and 0.14 in Rainbow Trout. For belly thickness it was found to be 0.17 in both species. The heritabilities for dressing percentage and flesh colour did not differ significantly from zero.

The genetic correlation between weight of fish ungutted and gutted was estimated at 1.00 in both species and between these traits and length close to 0.90 . Between belly thickness and weight/length it was also high. Between maturity and the other traits the genetic correlations were positives; medium in Salmon and low in Rainbow Trout.

\section{Growth rate and mortality of crosses between strains of Atlantic Salmon}

\author{
B. GJERDE \\ Department of Animal Genetics and Breeding \\ Agricultural University of Norway, $1432 \stackrel{\circ}{A} s-N L H$, Norway
}

Five different strains of Atlantic Salmon (Salmo salar) were used in a diallel cross. Mortality of eyed eggs, alevins, fry and fish after 2 years in the sea, have been studied. No significant differences between crosses and purebred and between strains with regard to general and specific combining ability were found for any of the traits studied.

It is concluded that crossbreeding of strains are of little interest in a future breeding program for Atlantic Salmon. 